Institute of

Public Finance
NEWSLETTER

AN OGGASIONAL PUBLIGATION OF THE INSTITUTE OF PUBLIG FINANGE

\title{
Employment at the local government level in the Republic of Groatia during the economic crisis
}

\author{
JOSIP FRANIĆ Institute of Public Finance
}

\section{SUMMARY}

Despite the economic crisis and the need to reduce public expenditure, the total number of budget employees in units of local and regional self-government in the Republic of Croatia increased by slightly more than $15 \%$ over the period 2008-II. Apart from a nominal increase in expenses for employees, the share of these expenses in total local and regional budget expenditure also went up. Consequently, a substantial number of the units have found themselves in a situation where the bulk of their expenditures are spent on employees, leaving them without sufficient funds to perform their functions. Given that no new unit was established in the reference period, nor were there any major decentralisation breakthroughs that would require the creation of new jobs, such circumstances may be a sign of an irresponsible policy on providing for the unemployed at the expense of local and regional budgets.

\section{INTRODUGTION}

The treatment of local and regional budget employees is a highly important and sensitive issue. A fall in budget revenue requires reductions in overall expenditure, where increasing the number of employees is the least desired option. On the other hand, reducing the number of employees leads to a further rise in unemployment, which aggravates the welfare situation within a community, already destabilised by the crisis. Moreover, due to a general shortage of qualified employees, especially in underdeveloped and rural areas, it is very difficult to compensate for the lost professional staff later on, which is why the dismissing of employees is not desirable either. Against such a background, the best way to cut down expenses is to reduce working hours or, as a last resort, to cut salaries. While some EU member states, like Ireland and Denmark, have resorted to staff reductions at the local level, the largest savings were achieved exactly by reducing or freezing salaries and reducing the work-week hours.

Based on the budget reports submitted to the Ministry of Finance by units of local and regional self-government (hereinafter: local units), this paper analyses movements in the number of employees in the administrative bodies and users ${ }^{2}$ of local and regional government budgets after the outbreak of the 2008 economic crisis. The inclusion in the analysis of employees in public utilities and other companies in majority ownership of the local units would have provided a much more realistic picture, but, due to the unavailability of detailed data, these categories have been omitted from the analysis.

I For example, salaries at the local government level have decreased by $5 \%$ in Spain, $15 \%$ in Estonia and $25 \%$ in Romania. In Latvia, work week has been reduced to 4 days, and in Great Britain, the salaries of all public sector employees have been frozen. For more details about the treatment of employees at the local government level, see Council of Europe (2OI2).

2 Employees in the bodies are civil servants and civil service employees performing administrative and professional tasks within the scope of activities of a particular local unit (e.g. in the City Council), and employees in budget users are those employed with institutions, councils and funds established by local units and financed $50 \%$ or more from the local units' budgets (kindergartens, museums, etc.). Unless particularly emphasized, the data presented in the paper relate to the total number of employees, i.e. the sum of employees in the bodies and in budget users. 


\section{GONTINUED GROWTH OF EMPLOYMENT AT THE LOGAL GOVERNMENT LEVEL}

Despite the need to reduce total expenditure and expenses for employees, employment at the expense of the local and regional budgets in the Croatia has grown continuously during the economic crisis. During the period 2008-II, 5,350 new jobs were created (of which slightly more jobs were opened in budget users than in the bodies), an increase of I5.2\% from 2007 (Table I).
As many as 408 of a total of 576 local units increased the number of employees; 86 of them made no changes, whereas 82 reduced employment (Chart I). An inevitable consequence of such increases is also the growth in expenses for employees, which went up by almost one billion kuna over the reference period (Table 2).

As no new units were established in the reference period, nor were there any major decentralisation breakthrou-

\section{Table I}

Number of employees in the bodies and budget users at the local level (2007-II)

\begin{tabular}{|c|c|c|c|c|c|c|c|}
\hline & & 2007 & 2008 & 2009 & 2010 & 2011 & $\begin{array}{c}\text { Increase/Decrease in the } \\
2007-11 \text { period (in } \%)\end{array}$ \\
\hline \multirow{5}{*}{ in the bodies } & Counties & 1,625 & 2,070 & 2,I75 & 2,I42 & 2,076 & 27.8 \\
\hline & Zagreb* & 2,799 & 2,758 & 2,778 & 2,760 & $2,74 \mathrm{I}$ & -2.1 \\
\hline & Cities & 5,273 & 5,754 & 6,167 & 6,IOI & 6,385 & 2I.I \\
\hline & Municipalities & $3, \mathrm{I} 23$ & 3,359 & 3,864 & 3,834 & $4, \mathrm{OI} 8$ & 28.7 \\
\hline & Total & $\mathrm{I} 2,82 \mathrm{O}$ & I3,94I & 14,984 & $\mathrm{I} 4,837$ & 15,220 & I8.7 \\
\hline \multirow{5}{*}{ in budget users } & Counties & I,6I4 & $\mathrm{I}, 897$ & $2,28 \mathrm{I}$ & 2,0I9 & 2,158 & 33.7 \\
\hline & Zagreb & $7,6 \mathrm{I3}$ & 7,820 & 7,826 & 7,888 & 8,000 & $5 . I$ \\
\hline & Cities & 12,378 & $\mathrm{I} 2,834$ & I3,049 & $\mathrm{I3}, 6 \mathrm{I} 2$ & 13,924 & $\mathrm{I} 2.5$ \\
\hline & Municipalities & 886 & 999 & $\mathrm{I}, \mathrm{O} 73$ & $\mathrm{I}, \mathrm{I} 98$ & I,359 & 53.4 \\
\hline & Total & $22,49 \mathrm{I}$ & 23,550 & 24,229 & $24,7 \mathrm{I} 7$ & $25,44 \mathrm{I}$ & I3.I \\
\hline Total employees & & $35,3 \mathrm{II}$ & 37,491 & 39,213 & 39,554 & $40,66 I$ & 15.2 \\
\hline
\end{tabular}

* Due to its special status as both a city and a county, the City of Zagreb is presented separately.

Source: Ministry of Finance; author's calculation.

\section{Chart I}

An overview of counties, cities and municipalities with respect to changes in total employment (2007-II)

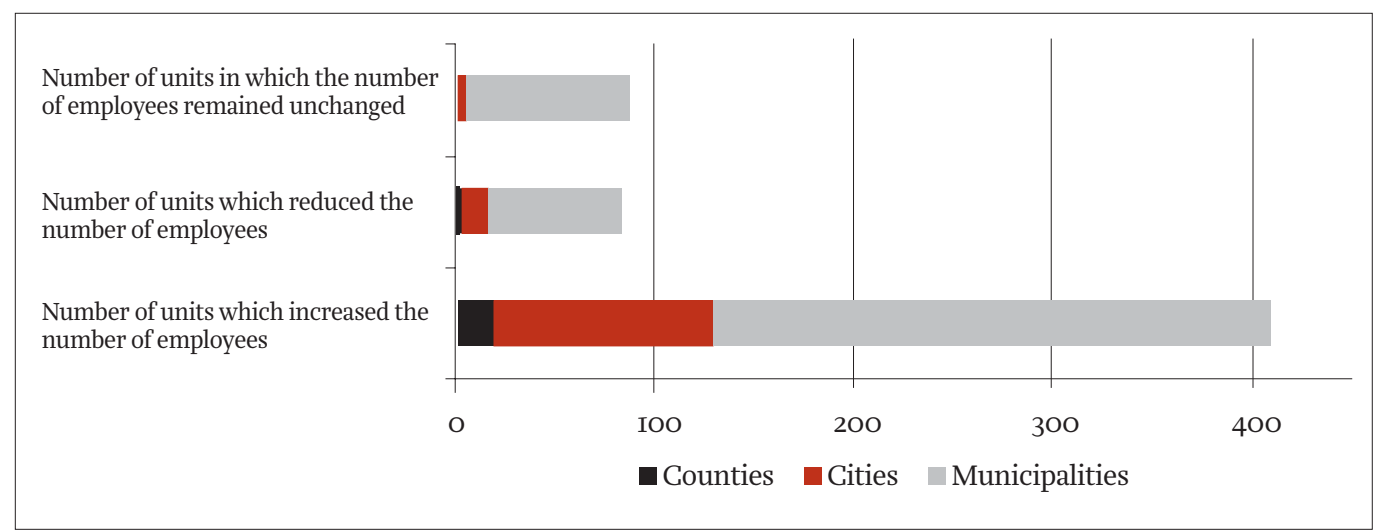

Source: Ministry of Finance; author's calculation.

Only the City of Zagreb reduced the number of employees in the bodies (but, owing to employment in budget users, total employment at the expense of the City of Zagreb budget went up), while an increase in employment was recorded at all other levels of government (counties, cities and municipalities), both in the bodies and in budget users, especially in 2008 and 2009. After a slowdown in 20IO, employment rose again in 20II, with I,IO7 newly created jobs for the whole of the Croatia. ghs that would require new job creation, the presented situation may be a sign of an irresponsible policy of providing for the unemployed at the expense of local and regional budgets ${ }^{3}$, regardless of the serious financial difficulties caused by the economic crisis. More specifically, the increase in the number of unemployed persons and in expenses for employees strongly affected the negative

3 For more details about decentralisation in the Croatia, see EIZG (2OIO). 
Table 2

Expenses for employees at the local level, 2007-II (in million kuna)

\begin{tabular}{|c|c|c|c|c|c|c|c|}
\hline & & 2007 & 2008 & 2009 & 2010 & 2011 & $\begin{array}{l}\text { Increase/Decrease in the } \\
\text { period } 2007 \text {-II (in \%) }\end{array}$ \\
\hline \multirow{5}{*}{ in the bodies } & Counties & 244.2 & 335.8 & 369.2 & 365.1 & 354,2 & 45.0 \\
\hline & Zagreb & 404.5 & 432.4 & 443.0 & 442.6 & 448,4 & IO.9 \\
\hline & Cities & 683.9 & 787.7 & 850.6 & 839.1 & 845,8 & 23.7 \\
\hline & Municipalities & 3II.I & 353.I & 398.I & $4 \mathrm{IO} .2$ & 427,7 & 37.5 \\
\hline & Total & $\mathrm{I}, 643.8$ & I,909.I & $2,060.9$ & $2,057.0$ & 2,O76,I & 26.3 \\
\hline \multirow{5}{*}{ in budget users } & Counties & IO3.7 & I35.4 & I5O.3 & $\mathrm{I} 78.8$ & 204,6 & $97 \cdot 3$ \\
\hline & Zagreb & 874.9 & 977.4 & $\mathrm{I}, \mathrm{O} 44.8$ & $\mathrm{I}, \mathrm{O} 39.4$ & $\mathrm{I}, \mathrm{O} 39,2$ & $\mathrm{I} 8.8$ \\
\hline & Cities & $\mathrm{I}, \mathrm{O} 8 \mathrm{O} .5$ & I,20I.9 & $\mathrm{I}, 299.5$ & I,299.0 & $\mathrm{I}, 3 \mathrm{I} 5,9$ & 2I. 8 \\
\hline & Municipalities & 59.0 & 74.9 & 88.0 & 94.2 & IO4,I & 76.5 \\
\hline & Total & 2,II8.I & $2,389.5$ & $2,582.6$ & $2,6 \mathrm{II} .4$ & $2,663,9$ & 25.8 \\
\hline \multicolumn{2}{|c|}{ Total expenses for employees } & $3,761.8$ & $4,298.5$ & $4,643.6$ & $4,668.4$ & $4,740.0$ & 26,0 \\
\hline
\end{tabular}

Source: Ministry of Finance; author's calculation.

primary balance outturns for local governments in the Croatia (Chart 2). The primary balance is the difference between overall revenue (operating revenues and revenues from non-financial assets selling) and overall expense (operating expenses and expenses for the non-financial assets acquisition) excluding interest paid on previously assumed liabilities. In addition to own revenues, revenues from tax sharing and aid received from the state budget and from abroad, the Budget Act (Zakon o proračunu, NN $87 / 08^{4}$ ) allows municipalities, cities, counties and the City of Zagreb to derive receipts from borrowing in the form of credit and loans and from the issuance of securities. Therefore, the payment of interest is the consequence of previously incurred liabilities and, by excluding it, we get a more realistic insight into the current policy contribution to the total balance of local units.
Chart 2 shows that, after a period of relative stability from 2002-07, financial difficulties cropped up at the local government level as early as 2008, but the primary deficit reached its peak (HRK I.77bn) in 2009. That year, over $70 \%$ of all the local units incurred deficits, and the previously mentioned increases in employee expenses definitely contributed to such a huge primary deficit.

Not even the serious fiscal difficulties (the revenue gap and the need to reduce expenditure) could prevent some local units from hiring new employees. Table 3 presents local units with the largest budget deficits after the emergence of the economic crisis. While the creation of some of the new jobs can probably be well justified, such huge increases in the number of and expenses for employees are certainly uncommon given the deepening crisis.

\section{Chart 2}

Primary balance of local governments, 2002-II (in million kuna)

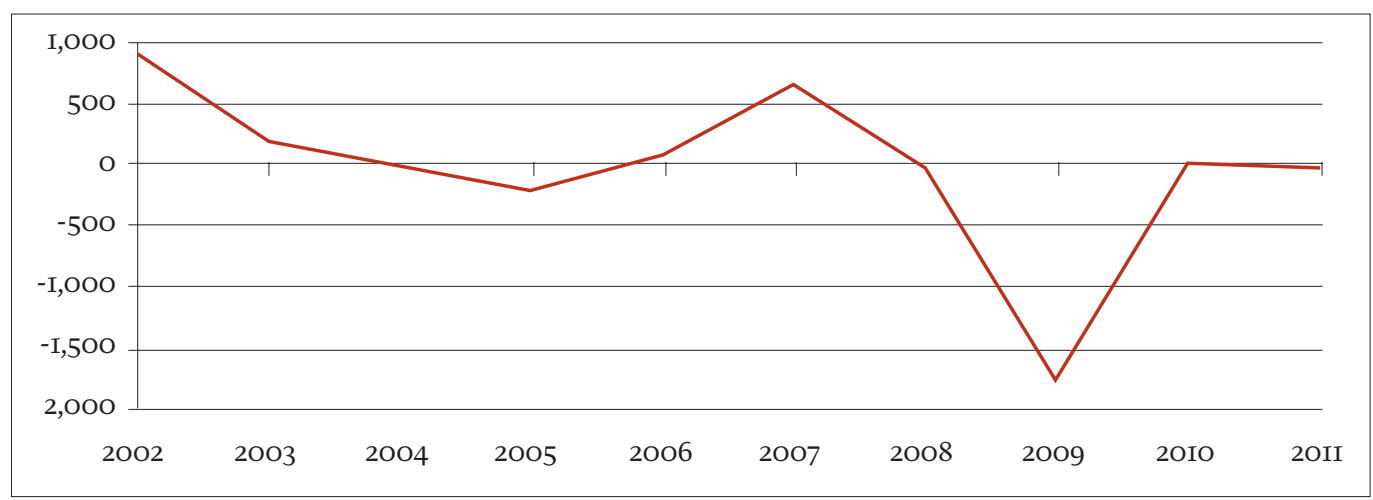

Source: Ministry of Finance; author's calculation.

4 Only available in Croatian, translator's note. 
Table 3

Counties, cities and municipalities with the largest budget deficits after the outbreak of the economic crisis

\begin{tabular}{|c|c|c|c|c|c|c|c|c|}
\hline & & & 2007 & 2008 & 2009 & 2010 & 2011 & $\begin{array}{c}\text { Increase/ Decrease in the } \\
2007-\text {-II period (in \%) }\end{array}$ \\
\hline \multirow{9}{*}{ نٍ } & \multirow{3}{*}{ C. of Lika-Senj } & budget balance (in \%) & 0.0 & -6.0 & -5.3 & -3.5 & -6.8 & - \\
\hline & & total number of employees & 86 & 86 & $145^{*}$ & 83 & 85 & $-\mathrm{I} .2$ \\
\hline & & expenses for employees (in million kuna) & II.52 & 14.25 & I4.6I & 14.33 & 14.88 & 29.2 \\
\hline & \multirow{3}{*}{$\begin{array}{l}\text { C. of } \\
\text { Međimurje }\end{array}$} & budget balance (in \%) & I.2 & $-\mathrm{I} .4$ & -8.3 & -15.9 & -5.7 & - \\
\hline & & total number of employees & $6 \mathrm{II}$ & 76 & 78 & 75 & $8 \mathrm{I}$ & 32.8 \\
\hline & & expenses for employees (in million kuna) & 7.75 & II.I3 & I2.93 & I3.15 & 13.20 & 70.3 \\
\hline & \multirow{3}{*}{$\begin{array}{l}\text { C. of Bjelovar- } \\
\text { Bilogora }\end{array}$} & budget balance (in \%) & -2.3 & -4.5 & -23.9 & -13.5 & 2.6 & - \\
\hline & & total number of employees & 65 & 108 & Io6 & 107 & 107 & 64.6 \\
\hline & & expenses for employees (in million kuna) & 9.83 & 13.89 & 15.36 & 15.70 & 13.54 & 37.7 \\
\hline \multirow{9}{*}{ : } & \multirow{3}{*}{ Županja } & budget balance (in \%) & 0.9 & $-2 \mathrm{I} .4$ & -3.6 & -O.I & -35.2 & - \\
\hline & & total number of employees & 87 & 86 & 88 & 94 & 142 & 63.2 \\
\hline & & expenses for employees (in million kuna) & 7.15 & 8.07 & 8.66 & $8.9 \mathrm{I}$ & IO.II & 4I.4 \\
\hline & \multirow{3}{*}{ Rijeka } & budget balance (in \%) & -0.4 & $-\mathrm{I} 2.6$ & -5.5 & -15.4 & -16.0 & - \\
\hline & & total number of employees & $\mathrm{I}, 5 \mathrm{I} 6$ & $\mathrm{I}, 592$ & I,6I6 & $\mathrm{I}, 625$ & $\mathrm{I}, 624$ & 7.1 \\
\hline & & expenses for employees (in million kuna) & $177.4 \mathrm{I}$ & 201.40 & 209.18 & 194.65 & I9I.90 & 8.2 \\
\hline & \multirow{3}{*}{ Đakovo } & budget balance (in \%) & 17.0 & 0.3 & -22.8 & -I8.I & $-\mathrm{I} 4.2$ & - \\
\hline & & total number of employees & 93 & 95 & IOO & 99 & $\mathrm{IO} 3$ & IO.8 \\
\hline & & expenses for employees (in million kuna) & 6.57 & 7.38 & 8.19 & 8.49 & 8.17 & 24.3 \\
\hline \multirow{11}{*}{ 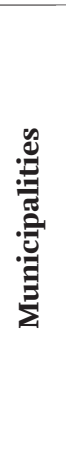 } & \multirow{3}{*}{ Dugopolje } & budget balance (in \%) & 61.9 & 59.5 & -47.4 & -67.5 & -63.4 & - \\
\hline & & total number of employees & 6 & 6 & 8 & 7 & IO & 66.7 \\
\hline & & expenses for employees (in million kuna) & $\mathrm{I} .2 \mathrm{I}$ & 1.73 & I.98 & 2.14 & 2.26 & 85.9 \\
\hline & \multirow{4}{*}{ Poličnik } & & & & & & & \\
\hline & & budget balance (in \%) & -7.5 & 0.7 & 87.8 & -56.2 & $-52 . I$ & - \\
\hline & & total number of employees & $\mathrm{I} 6$ & $2 \mathrm{2I}$ & 27 & 26 & 28 & 75.0 \\
\hline & & expenses for employees (in million kuna) & 1.20 & $\mathrm{I} .74$ & 2.27 & 2.24 & 2.30 & 92.2 \\
\hline & & & & & & & & \\
\hline & \multirow{3}{*}{ Pokupsko } & budget balance (in \%) & 2I.4 & -20.0 & -23.7 & -8.7 & -47.8 & - \\
\hline & & total number of employees & 6 & 6 & 6 & 5 & 5 & -16.7 \\
\hline & & expenses for employees (in million kuna) & 0.65 & 0.74 & 0.80 & 0.74 & $0.7 \mathrm{I}$ & 9.6 \\
\hline
\end{tabular}

*Due to an increase in the number of employees in budget users from I9 to 82; as early as 2010, the number of employees in budget users again stood at 19. Source: Ministry of Finance; author's calculation.

Despite permanent deficits, 20 new jobs were opened in the County of Međimurje, with expenses for employees going up by $70 \%$ over the reference period. Despite having one employee less in 2011 than in 2007, the County of Lika-Senj markedly increased its expenses for employees. Expenses for employees rose by 41.4\% in Županja, and almost doubled in the municipalities of Dugopolje and Poličnik, which certainly contributed to such huge budget deficits.

However, given the large number of local units and considerable differences among them, it is not advisable to generalise about the data when it comes to employment during the economic crisis. As already mentioned, there is a certain number of local units which have not chan- ged, but have even reduced the number of employees. Table 4 therefore singles out the counties, cities and municipalities with the largest increases and those with the largest decreases in employment after 2007.

Most new jobs were created in the counties of Sisak-Moslavina, Šibenik-Knin and Karlovac. In the town of Otok, the number of employees increased from to to 60 in only three years (the bulk of the jobs were opened in the city administration bodies).

The number of employees in the municipalities of Satnica Đakovačka and Podcrkavlje rose from I to I6 and from 2 to I6 respectively (in both of these municipalities, all the employees work in the municipal administration bodies). 
Table 4

Counties, cities and municipalities with the largest increases/decreases in the total number of employees after the outbreak of the economic crisis

Largest increases in employees

Largest decreases in employees

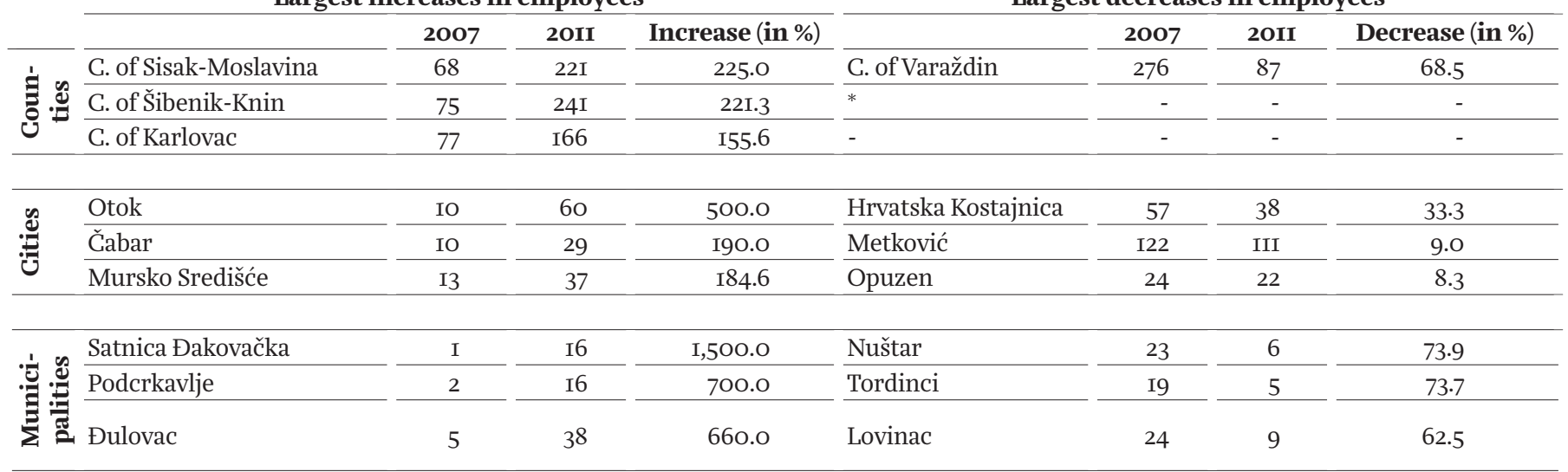

* Apart from the County of Varaždin, only the County of Lika-Senj reduced the number of employees during the reference period, but by only one person (from 86 to 85 ).

Source: Ministry of Finance; author's calculation.

The most severe reductions in employment were recorded in the cities of Hrvatska Kostajnica, Metković and Opuzen, and in the municipalities of Nuštar, Tordinci and Lovinac, while, among the counties, only the County of Varaždin made a significant staff cut (the County of LikaSenj also reduced the number of employees during the reference period, but only insignificantly (by one employee, see Table 3).

\section{THE GONSEQUENGES OF RUNAWAY EMPLOYMENT}

The growth of expenses for employees on the one hand, and a need to cut overall expenditure on the back of a fall in revenue on the other, led to an increase in the share of expenses for employees in the local units' budget expenditures. Chart 3 shows movements in overall revenue and expenditure, as well as in expenses for employees at the local and regional levels in the RC from 2002 to 2011.

\section{Chart 3}

Movements in overall budget revenue and expenditure and in expenses for employees at the local level, 2002-II (in million kuna)

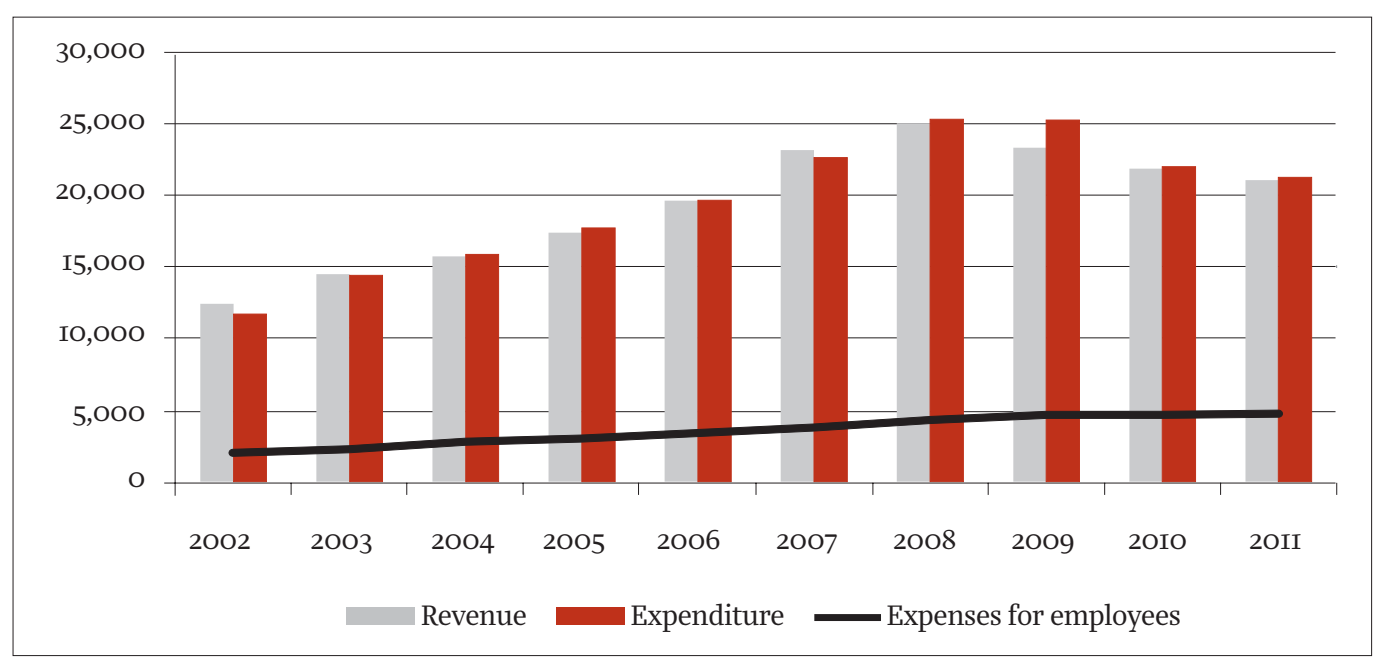

Source: Ministry of Finance; author's calculation. 
Expenses for employees grew continuously throughout the reference period, while overall expenditure decreased after 2008, suggesting that savings were achieved in other expenditure items (primarily the environmental protection area, e.g. waste disposal and waste water management, and also in water supply, street illumination costs, etc.). As a result, the share of expenses for employees in the local units' total budget expenditure increased on average from $16.6 \%$ in 2007 to $22.3 \%$ in 2011 (Chart 4). text of the local units' capacities to finance their own budget expenditures. Specifically, one of the greatest challenges facing the local governments in the Croatia is their heavy dependence on various types of aid (mostly provided from the central government budget, but also by general government entities, foreign governments and international organisations). The share of aid in budget revenue for every fourth municipality and almost every seventh city exceed 30\%, where the share for 3 cities and 44

\section{Chart 4.}

Share of expenses for employees in total budget expenditure, 2007-II (in \%)

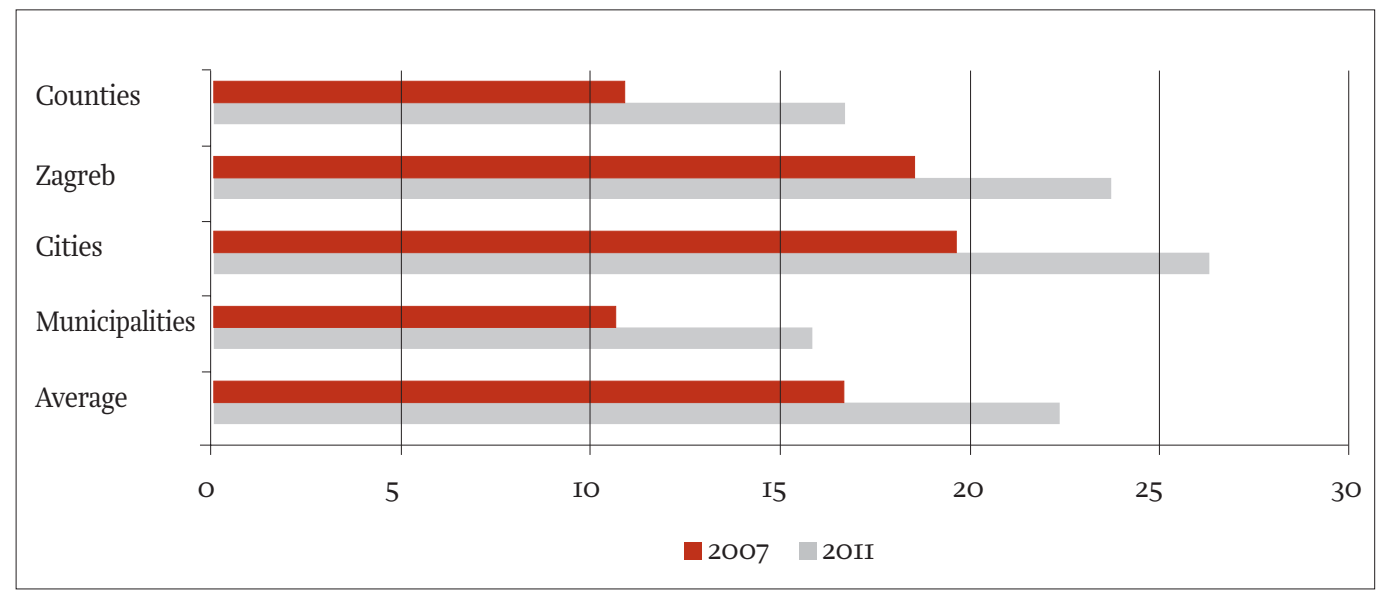

Source: Ministry of Finance; author's calculation.

As shown in Table 5, the shares of expenses for employees exceeded 30\% in only 5 cities in 2007, but this number rose to 29 cities in 20II, four of which had the shares exceeding $40 \%$ of the total. A similar situation is found at the municipality level.

The increase in the number of employees and in expenses for employees in local units should be viewed in the con- municipalities exceeds 50\% (Chart 5). In 20II, as many as 7 counties derived more than half of their total budget revenues from aid received.

Table 6 gives an overview of local units with the largest shares of aid received in their total budget revenues in 20II. Despite the fact that the performance of these units' functions depended to a large extent on aid received, of

\section{Table 5}

Distribution of the counties, cities and municipalities according to the share of expenses for employees in total budget expenditure (a comparison between the 2007 and 2011 data)

\begin{tabular}{|c|c|c|c|c|c|c|c|}
\hline & & $<5 \%$ & $5-10 \%$ & 10-20\% & $20-30 \%$ & $30-40 \%$ & $>40 \%$ \\
\hline \multirow{2}{*}{ Counties } & 2007 & $\mathrm{O}$ & IO & 9 & I & $\mathrm{O}$ & $\mathrm{O}$ \\
\hline & $2 \mathrm{OII}$ & $\mathrm{O}$ & 4 & $\mathrm{I} 2$ & 4 & $\mathrm{O}$ & $\mathrm{O}$ \\
\hline \multirow{2}{*}{ Cities } & 2007 & $\mathrm{O}$ & I5 & 49 & 58 & 5 & $\mathrm{O}$ \\
\hline & $2 \mathrm{OII}$ & $\mathrm{O}$ & I & 16 & $8 \mathrm{I}$ & 25 & 4 \\
\hline \multirow{2}{*}{ Municipalities } & 2007 & 40 & 156 & I90 & 35 & 7 & I \\
\hline & $2 \mathrm{OII}$ & 5 & 56 & 234 & 107 & I9 & 8 \\
\hline
\end{tabular}

Note: For easier reference, in Table 5 and Chart 5 Zagreb is categorised as a city.

Source: Ministry of Finance; author's calculation. 


\section{Chart 5}

Distribution of counties, cities and municipalities according to the share of aid received in total budget revenue (20II)

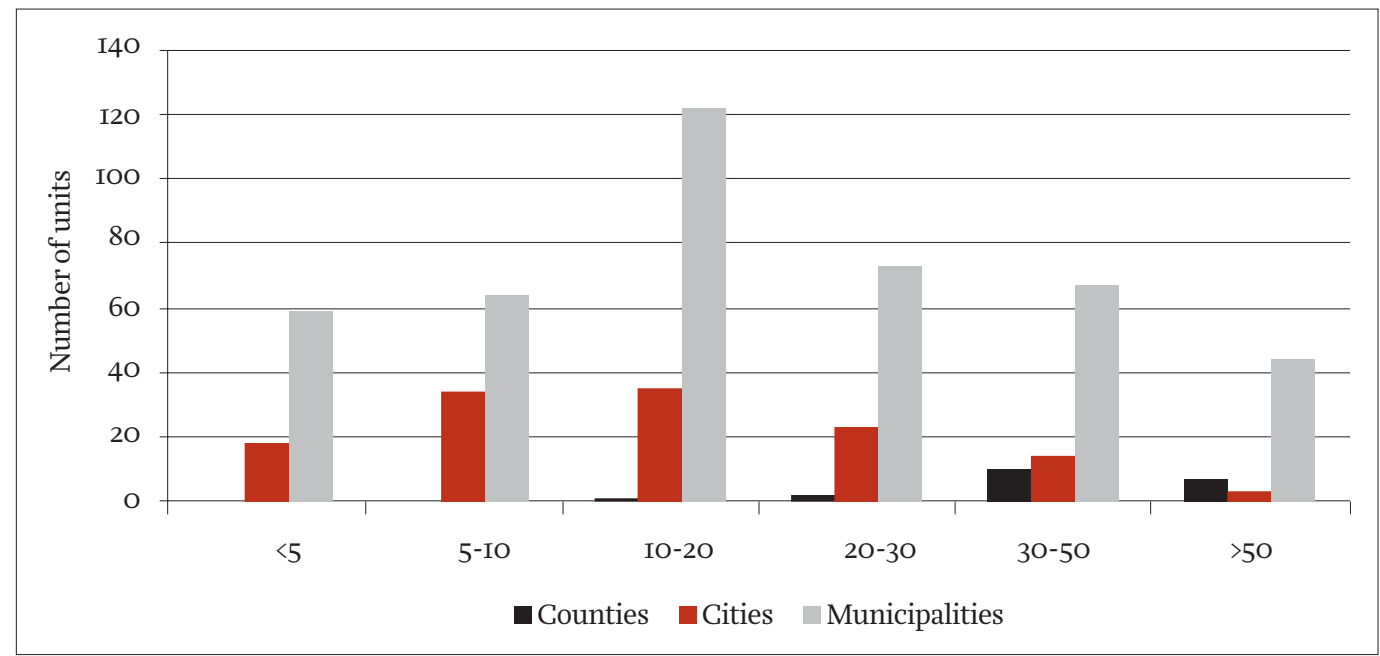

Source: Ministry of Finance; author's calculation.

\section{Table 6}

Counties, cities and municipalities with the largest shares of aid received in their budget revenues (2007-II)

\begin{tabular}{|c|c|c|c|c|c|c|c|c|}
\hline & & & 2007 & 2008 & 2009 & 2010 & $20 I I$ & $\begin{array}{l}\text { Increase/Decrease in } \\
\text { the period } 2007-\text { II (in \%) }\end{array}$ \\
\hline \multirow{9}{*}{ ن } & \multirow{3}{*}{ C. of Požega- Slavonia } & share of aid in revenue (in \%) & 2I.I & 32.I & 29.2 & 18.5 & 72.I & - \\
\hline & & number of employees & I46 & 158 & $\mathrm{I} 77$ & I87 & 185 & 26.7 \\
\hline & & expenses for employees (in million kuna) & 7.89 & 8.40 & I2.39 & $\mathrm{I7} .94$ & I6.84 & II3.4 \\
\hline & \multirow{3}{*}{ C. of Lika-Senj } & share of aid in revenue (in \%) & 69.5 & 71.2 & 72.0 & 6.4 & 69.2 & - \\
\hline & & number of employees & 86 & 86 & I45 & 83 & 85 & $-\mathrm{I} .2$ \\
\hline & & expenses for employees (in million kuna & II.52 & $\mathrm{I} 4.25$ & I4.6I & I4.33 & $\mathrm{I} 4.88$ & 29.2 \\
\hline & \multirow{3}{*}{$\begin{array}{l}\text { C. of Virovitica- } \\
\text { Podravina }\end{array}$} & share of aid in revenue (in \%) & II. 4 & $\mathrm{I} 8.2$ & 17.5 & 19.7 & 67.3 & - \\
\hline & & number of employees & 43 & 57 & 64 & 63 & 73 & 69.7 \\
\hline & & expenses for employees (in million kuna & 5.43 & 8.14 & IO.I3 & IO.3I & 8.26 & 52.1 \\
\hline \multirow{9}{*}{ : } & \multirow{3}{*}{ Vrlika } & share of aid in revenue (in \%) & 46.2 & 46.1 & 42.9 & 37.5 & 73.I & - \\
\hline & & number of employees & I3 & I3 & I3 & I3 & $\mathrm{I} 2$ & -7.7 \\
\hline & & expenses for employees (in million kuna & I.5I & I.6o & I.66 & I.6I & I.56 & 3.2 \\
\hline & \multirow{3}{*}{ Hrvatska Kostajnica } & share of aid in revenue (in \%) & 20.7 & 29.8 & 35.9 & 28.2 & 7I.I & - \\
\hline & & number of employees & 57 & 57 & 56 & 37 & 38 & -33.3 \\
\hline & & expenses for employees (in million kuna & 3.69 & 3.87 & 3.63 & 2.97 & 3.18 & -13.8 \\
\hline & \multirow{3}{*}{ Metković } & share of aid in revenue (in \%) & 25.5 & $3 \mathrm{I} .3$ & 18.3 & 46.4 & 56.1 & - \\
\hline & & number of employees & $\mathrm{I} 22$ & 127 & $\mathrm{I} 24$ & II9 & III & -9.0 \\
\hline & & expenses for employees (in million kuna & 9.73 & II.39 & I2.07 & II.4I & IO.48 & 7.8 \\
\hline \multirow{11}{*}{ 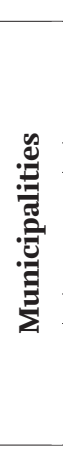 } & \multirow{4}{*}{ Ervenik } & & & & & & & \\
\hline & & share of aid in revenue (in \%) & 94.8 & 92.0 & 86.9 & 89.0 & 89.9 & - \\
\hline & & number of employees & 3 & 3 & $\mathrm{I} 2$ & 4 & 4 & 33.3 \\
\hline & & expenses for employees (in million kuna & 0.46 & 0.50 & 0.86 & 0.85 & 0.79 & 72.7 \\
\hline & \multirow{4}{*}{ Kistanje } & & & & & & & \\
\hline & & share of aid in revenue (in \%) & 80.3 & 82.7 & 84.4 & 84.6 & 85.I & - \\
\hline & & number of employees & IO & 9 & I2 & IO & I3 & 30.0 \\
\hline & & expenses for employees (in million kuna & 0.86 & I.I4 & $\mathrm{I} .32$ & I.08 & I.O7 & 23.4 \\
\hline & \multirow{3}{*}{ Civljane } & share of aid in revenue (in \%) & 91.9 & 87.4 & 92.6 & 88.0 & 85.I & - \\
\hline & & number of employees & 5 & 5 & 5 & 5 & 4 & -20.0 \\
\hline & & expenses for employees (in million kuna & O.5I & 0.55 & 0.58 & 0.63 & 0.53 & 4.0 \\
\hline
\end{tabular}

Source: Ministry of Finance; author's calculation. 
all the selected units, only Hrvatska Kostajnica made economies in expenses for employees after the crisis breakout, while other units even increased these expenses. For example, the municipality of Ervenik, in which aid received accounted for almost 90\% of the total budge revenue in $201 \mathrm{I}$ (the share was even larger in some years), almost doubled its expenses for employees. Similarly, the County of Senj-Lika, the cities of Vrlika and Metković and the municipality of Civljane reduced their staff numbers, but increased the expenses for employees. These examples clearly show that such a situation is unsustainable and that more substantial changes at the local government level are needed in the Croatia.

\section{GONGLUSION}

Despite the need for expenditure cuts after the outbreak of the economic crisis, a large number of local units continued to employ staff at the expense of their budgets, which further exacerbated an already grave financial situation. Many units found themselves in a situation where they could only provide funds to finance the salaries, contributions and other costs of employees, but had not enough resources to finance their statutory functions (the development of settlements and housing estates, public utility management, social welfare, health care, education, culture, physical education and sports, fire prevention and civil defence, etc.), and where they heavily depended on aid from abroad and from general government entities (primarily the central budget aid). The very fact that 54 local units derived more than half of their revenues from various forms of aid shows that they were incapable of performing their functions independently. Should they even increase the number of employees and/ or expenses for employees during the crisis, the purpose of their further existence would be called into question and it would be imperative that the number of local units be reduced. Reducing the number of local units would not only enable the central government to cut its aid allocations, but would also improve the supervision of local governments in the Croatia and, consequently, the quality of public services.

\section{REFERENGES}

Audit commission, 2010. Surviving the crunch: local finances in the recession and beyond. Available at: [http:// www.audit-commission.gov.uk/SiteCollectionDocuments/AuditCommissionReports/NationalStudies/ 20I00323survivingthecrunch.pdf].

Bajo, A. and Jurlina-Alibegović, D., 2008. Javne financije lokalnih jedinica vlasti. Zagreb: Školska knjiga : Institut za javne financije : Ekonomski institut Zagreb.

Bajo, A., 2009. "The structure of employment in local government units". Newsletter No. 43. Available at: [http://www.ijf.hr/eng/newsletter/43.pdf].

GBS, 20IIa. Firsts Releases and Statistical Reports. Zagreb: Croatian Bureau of Statistics.

GBS, 20Irb. Statistical Yearbook of the Republic of Croatia. Zagreb: Croatian Bureau of Statistics.

Council of Europe, 2012. Local Government in Critical Times: Policies for Crisis, Recovery and a Sustainable future. Available at: [https://wcd.coe.int/com.instranet. InstraServlet?command=com.instranet.CmdBlobGet \&InstranetImage $=2056216 \&$ SecMode $=I \& D o c I d=I 873$ $672 \&$ Usage $=2]$.

EIZG, 20I0. A Background Paper for Efficient Decentralisation in Croatia. Project study. Zagreb: Institute of Economics Zagreb.

Kesner-škreb, M., 1993. "Proračunski deficit”. Financijska praksa, I7 (5), 475-477.

Ministry of Finance of the Republic of Groatia; available at: [www.mfin.hr].

Zakon o Gradu Zagrebu, NN 90/92, 76/93, 69/95, I4/97, 36/98, 62/oI, I25/o8, 36/og. Zagreb: Narodne novine. Zakon o proračunu, NN 87/o8. Zagreb: Narodne novine. 